\title{
Effects of sulindac sulfide on proliferation and apoptosis of human breast cancer cell
}

\author{
HE-HUAN SUI ${ }^{1,2}$, YUN-JIANG ZHOU ${ }^{1}$, HU WANG $^{1}$, LI LI ${ }^{1}$, MIN CAO $^{1}$ and JIA-JUN HUANG ${ }^{1,2}$ \\ ${ }^{1}$ Department of Pharmacology; ${ }^{2}$ Chongqing Key Laboratory of Biochemistry and Molecular Pharmacology, \\ Chongqing Medical University, Chongqing 400016, P.R. China
}

Received January 12, 2016; Accepted June 2, 2017

DOI: $10.3892 / \mathrm{ol} .2018 .8331$

\begin{abstract}
The present study aimed to observe the effects of sulindac sulfide on the proliferation and apoptosis of human breast cancer cells MCF-7, and to explore the potential underlying molecular mechanism. The inhibitory ratio was detected using a cell counting kit- 8 assay. The changes in cell cycle distribution were assessed using flow cytometry (FCM). Furthermore, the changes in cell apoptosis rates were detected by Hoechst 33258 staining and FCM coupled with Annexin V-FITC/propidium iodide (PI) staining. In addition, the protein expression was detected using western blotting. Sulindac sulfide was able to inhibit the proliferation of breast cancer in a dose- and time-dependent manner. In addition, sulindac sulfide altered the cell cycle of breast cancer cells. The results of Hoechst 33258 staining and FCM coupled with Annexin V-FITC/PI staining demonstrated that sulindac sulfide could significantly induce the apoptosis of MCF-7 cells in a dose-dependent, and time-dependent manner. The western blot analysis demonstrated the protein expression of Bcl-2 was downregulated, and Bax and cleaved caspase-3 were upregulated. The results of the present study suggest that sulindac sulfide can inhibit the proliferation and induce the apoptosis of MCF-7 cells.
\end{abstract}

\section{Introduction}

Breast cancer is a type of malignant tumor that occurs in the epithelial tissue of the mammary gland, its incidence and mortality rates are one of the highest among malignant tumors in females worldwide (1). In China, the incidence of breast cancer is increasing and occurs at younger ages compared with previously (2). The causal factors and mechanisms of breast

Correspondence to: Professor Jia-Jun Huang, Department of Pharmacology, Chongqing Medical University, 1 Yi Xue Yuan Road, Yuzhong, Chongqing 400016, P.R. China

E-mail: huangjiajun1964@163.com

Key words: sulindac sulfide, breast cancer, MCF-7 cells, proliferation, apoptosis, caspase-3, apoptosis regulator Bax, apoptosis regulator $\mathrm{Bcl}-2$ cancer involve numerous factors, the proliferation and apoptosis of breast cancer cells has become a hotspot for correlative research $(3,4)$.

Nonsteroidal anti-inflammatory drugs (NSAIDs) are a chemically diverse drug type commonly used to treat inflammatory conditions and pain. The long-term use of NSAIDs has been investigated to reduce the risk of mortality from certain types of cancer (5). In addition, sulindac is widely used in clinical anti-infection medicine. Previously, a large number of studies have demonstrated that sulindac sulfide can effectively inhibit the proliferation and induce the apoptosis of various cancer cells (6-8). Although its use for patients with malignant disease has not been well investigated, numerous evidence suggests that it has potent cancer chemopreventive efficacy: Several publications have reported that sulindac sulfide can inhibit the invasion of colorectal, gastric and pancreatic cancer cells (9-12), but the mechanism remains unclear. In the present study, the effects of sulindac sulfide on the proliferation and apoptosis of human breast cancer cells MCF-7 treated with different concentrations, and durations were investigated. In addition, its potential molecular mechanism was explored. The current study may provide the experimental basis for clinical rational administration of sulindac sulfide.

\section{Materials and methods}

Materials. The human breast cancer MCF-7 cell line was purchased from the Type Culture Collection of the Chinese Academy of Sciences (Shanghai, China). Sulindac sulfide with 98\% purity was obtained from Sigma-Aldrich (Merck KGaA, Darmstadt, Germany), which was dissolved in DMSO at $80 \mu \mathrm{mol} / 1$ and stored at $-20^{\circ} \mathrm{C}$. The cell counting kit (CCK)-8 and Hoechst 33258 kits were obtained from Beyotime Institute of Biotechnology (Shanghai, China). The annexin V-FITC/propidium (PI) apoptosis kit was obtained from BD Biosciences (Franklin Lakes, NJ, USA). Antibodies directed against apoptosis regulator Bax (Bax; cat. no., 5023; dilution 1:1,000), apoptosis regulator $\mathrm{Bcl}-2$ (Bcl-2; cat. no., 2870; dilution 1:1,000) and caspase-3 (cat. no., 9665; dilution 1:1,000) were purchased from Cell Signaling Technology, Inc. (Danvers, MA, USA). Secondary rabbit (cat. no., DC20L; dilution 1:5,000), mouse (cat. no., 074-1809; dilution 1:5,000) and actin antibodies were obtained from Sigma-Aldrich (Merck $\mathrm{KGaA})$. An automatic microplate reader was obtained from 
Thermo Fisher Scientific, Inc. (Waltham, MA, USA). A flow cytometer was purchase from (Bio-Rad Laboratories, Inc., Hercules, CA, USA).

Cell culture. Human breast cancer MCF-7 cells were cultured in RPMI-1640 medium containing 10\% fetal bovine serum (Invitrogen; Thermo Fisher Scientific, Inc.), non-essential amino acids, $100 \mu \mathrm{g} / \mathrm{ml}$ streptomycin and $100 \mathrm{U} / \mathrm{ml}$ penicillin and maintained at $37^{\circ} \mathrm{C}$ in a humidified incubator with $5 \%$ $\mathrm{CO}_{2}$. Cells were collected in the growth phase for subsequent experiments.

Measurement of cell proliferation. Growth phase MCF-7 cells were seeded into 96 -well plates at a density of $1 \times 10^{5}$ cells $/ 200 \mu 1 /$ well in triplicates. Cells were incubated with different concentrations of sulindac sulfide $(20,40$ or $80 \mu \mathrm{mol} / \mathrm{l}$ ) and the control group was incubated in complete RPMI-1640 medium without sulindac sulfide. Following incubation times of 24,48 and $72 \mathrm{~h}, 20 \mu \mathrm{l}$ CCK- 8 agent was added to each well and incubated in a humidified incubator at $37^{\circ} \mathrm{C}$ for $1 \mathrm{~h}$. The optical density (OD) value was detected using an automatic microplate reader at $450 \mathrm{~nm}$. Three independent experiments were performed. The ratio of proliferation was calculated as follows: (1-OD/control OD) x100\%.

Cell cycle analysis. Analysis of the cell cycle was performed as described previously (13). Growth phase MCF-7 cells were seeded into 24 -well plates at $1 \times 10^{5}$ cells/800 $\mu 1 /$ well. These cells were incubated with different concentrations of sulindac sulfide for $48 \mathrm{~h}$, collected and fixed with $70 \%$ ethanol overnight at $4^{\circ} \mathrm{C}$. Prior to measuring, cells were rinsed thoroughly with PBS liquid centrifugal cast fixation fluid, and $1 \mathrm{ml}$ $100 \mathrm{mg} / \mathrm{l}$ RNA enzyme was added to each tube for cellular staining for $30 \mathrm{~min}$ at $37^{\circ} \mathrm{C}$. Then, PI tag was added to each tube and cells were incubated at room temperature in the dark for $30 \mathrm{~min}$, followed by flow cytometry. Three independent experiments were performed. Experience data were analyzed using FlowJo ModFit 3.2. (Tree Star, Inc., Ashland, OR, USA).

Hoechst 33258 staining. Growth phase MCF-7 cells were seeded into 24 -well plates at a density of $1 \times 10^{5}$ cells $200 \mu \mathrm{l} /$ well in triplicates. The cells incubated with different concentrations of sulindac sulfide $(20,40$ or $80 \mu \mathrm{mol} / \mathrm{l})$ and the control group was incubated in RPMI-1640 complete medium. Following the incubation for 24,48 or $72 \mathrm{~h}, 10 \mu 1$ Hoechst 33258 was added to each sample. Samples were then fixed with $4 \%$ paraformaldehyde for $25 \mathrm{~min}$ at room temperature, washed twice with PBS with $0.1 \%$ of Triton X-100. Images of samples of $\sim 200$ cell were captured using a fluorescent microscope at magnification, $\mathrm{x} 400$.

Apoptosis analysis. Apoptosis was measured using the Annexin V-FITC apoptosis detection kit according to the manufacturer's protocol (14). Growth phase MCF-7 cells were seeded into 6-well plates. The cells were incubated with different concentrations of sulindac sulfide for $72 \mathrm{~h}$, collected, washed twice in cold PBS, and incubated with $10 \mu 1$ of Annexin V-FITC and PI for $30 \mathrm{~min}$. Samples were measured using flow cytometry. Three independent experiments were performed. Experimental data were analyzed using ModFit LT (version 3.2; Verity Software House, Inc., Topsham, ME, USA).
Table I. Growth-inhibiting effects of sulindac sulfide on MCF-7 cells $(n=3)$.

Time, $\mathrm{h}$

\begin{tabular}{lccc}
\cline { 2 - 4 } Group & 24 & 48 & 72 \\
\hline Control & $2.83 \pm 1.2$ & $5.07 \pm 3.8$ & $8.25 \pm 2.4$ \\
$20 \mu \mathrm{mol} / 1$ & $6.41 \pm 3.3$ & $10.55 \pm 1.7$ & $15.37 \pm 2.0$ \\
$40 \mu \mathrm{mol} / 1$ & $15.24 \pm 2.5$ & $22.96 \pm 1.9$ & $30.01 \pm 3.2^{\mathrm{a}, \mathrm{b}}$ \\
$80 \mu \mathrm{mol} / 1$ & $56.72 \pm 2.8^{\mathrm{a}}$ & $65.01 \pm 3.1^{\mathrm{a}}$ & $73.54 \pm 1.3^{\mathrm{a}, \mathrm{b}}$ \\
\hline
\end{tabular}

${ }^{\mathrm{a}} \mathrm{P}<0.05$, compared with control at the same time point; ${ }^{\mathrm{b}} \mathrm{P}<0.05$, compared with $24 \mathrm{~h}$ of the same group $(n=3)$.

Table II. Effects of sulindac sulfide on cell cycle of MCF-7 cells using flow cytometry $(n=3)$.

\begin{tabular}{lccr}
\hline & \multicolumn{3}{c}{ Cell cycle, $\%$} \\
\cline { 2 - 4 } Group & $\mathrm{G}_{0} / \mathrm{G}_{1}$ & $\mathrm{~S}$ & $\mathrm{G}_{2} / \mathrm{M}$ \\
\hline Control & $23.1 \pm 2.7$ & $46.1 \pm 1.2$ & $30.8 \pm 3.6$ \\
$20 \mu \mathrm{mol} / 1$ & $42.2 \pm 2.9$ & $35.0 \pm 1.2$ & $11.9 \pm 1.6$ \\
$40 \mu \mathrm{mol} / 1$ & $68.5 \pm 1.9^{\mathrm{a}}$ & $21.2 \pm 1.2^{\mathrm{a}}$ & $10.3 \pm 1.0^{\mathrm{a}}$ \\
$80 \mu \mathrm{mol} / 1$ & $71.6 \pm 1.2^{\mathrm{a}}$ & $19.4 \pm 1.7^{\mathrm{a}}$ & $9.0 \pm 0.6^{\mathrm{a}}$ \\
\hline
\end{tabular}

${ }^{\mathrm{a}} \mathrm{P}<0.05$, compared with control group $(\mathrm{n}=3)$.

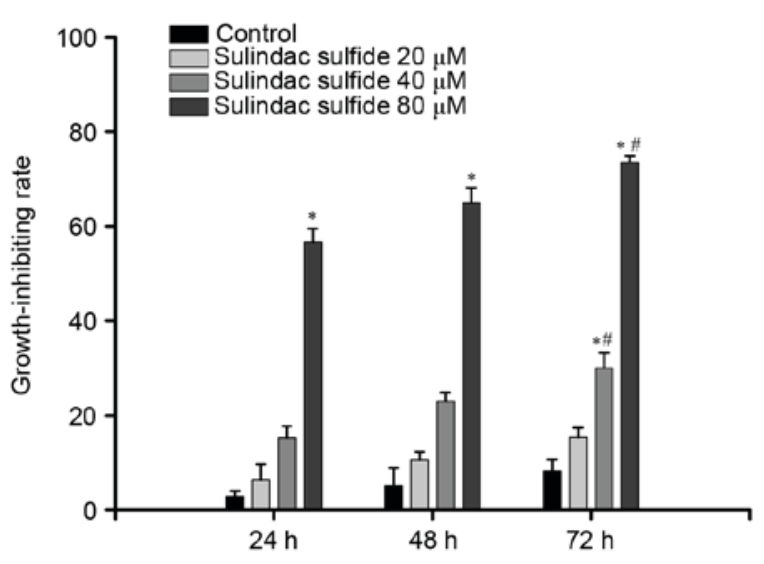

Figure 1. Sulindac sulfide function was monitored using a cell counting kit- 8 assay. MCF-7 cells were incubated for different duration with various concentrations of sulindac sulfide (20,40 or $80 \mu \mathrm{mol} / 1)$. Sulindac sulfide was demonstrated to significantly inhibit cell proliferation compared with the untreated control group. ${ }^{*} \mathrm{P}<0.05$, compared with control at the same time point; ${ }^{\#} \mathrm{P}<0.05$, compared with $24 \mathrm{~h}$ of the same group $(\mathrm{n}=3)$.

Western blot analysis. Analysis of western blotting was performed as described previously (15). Cells $\left(2 \times 10^{6}\right)$ were seeded into 6-well plates at a density of 2,000 $\mu \mathrm{l} /$ well and were treated with different concentrations of sulindac sulfide or the control. Cells were washed with PBS, then total protein was extracted using a Total protein extraction kit (Keygentec, Inc., Nanjing, China). Proteins were quantified using a BCA 

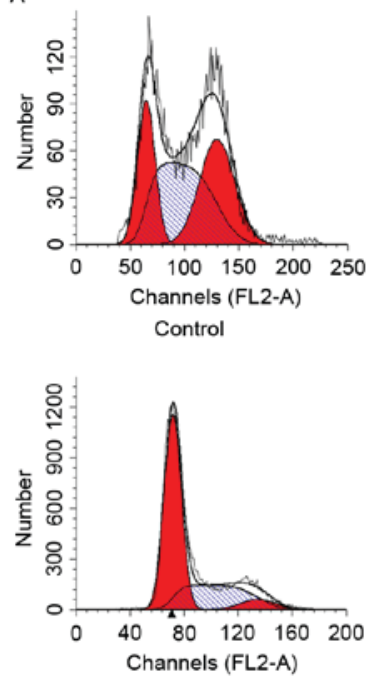

c

Sulindac sulfide 40

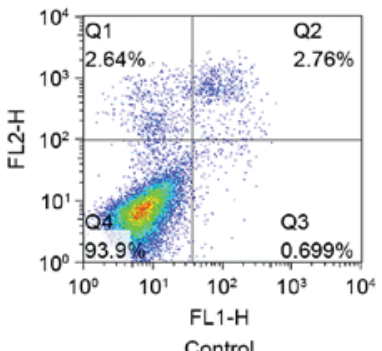

Control

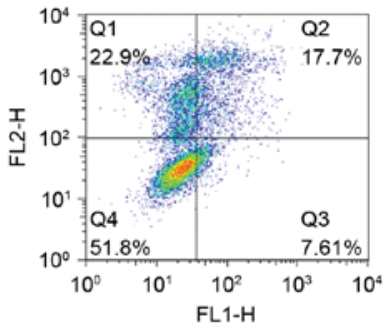

Sulindac sulfide $40 \mu \mathrm{M}$
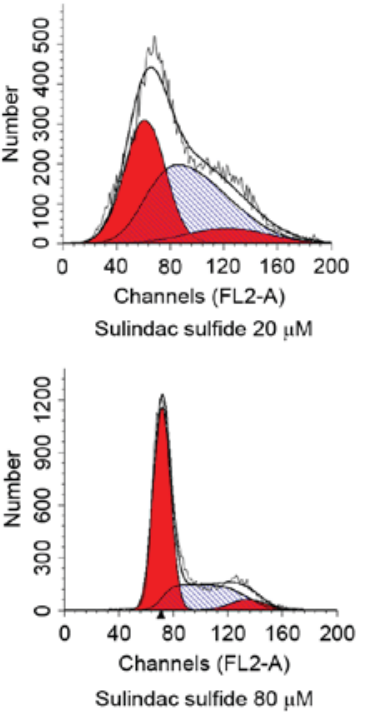

Sulindac sulfide $80 \mu \mathrm{M}$

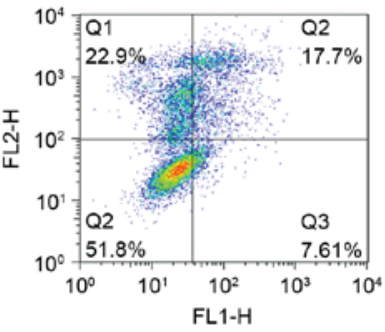

Sulindac sulfide $20 \mu \mathrm{M}$

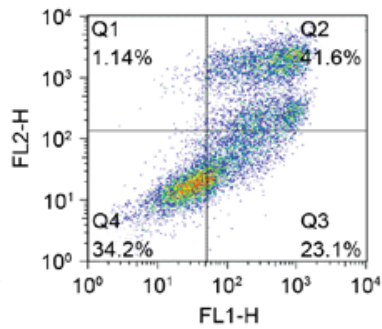

Sulindac sulfide $80 \mu \mathrm{M}$

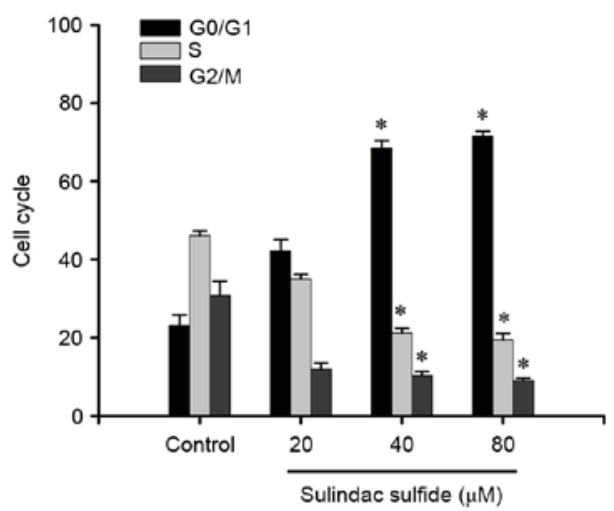

D

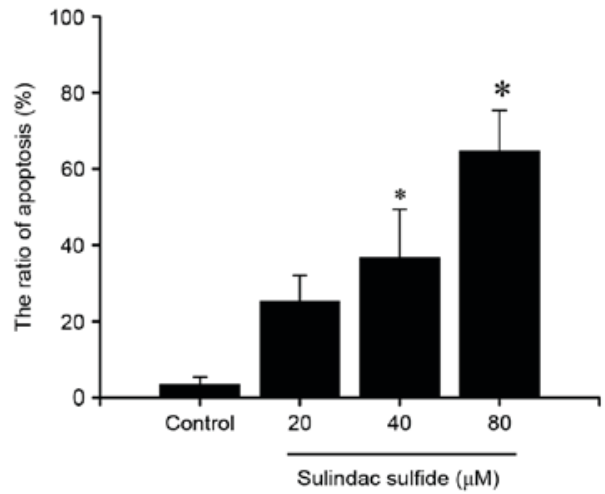

Figure 2. Sulindac sulfide function was monitored using flow cytometry. (A) Percentage of MCF-7 cells in different cell cycle phases. (B) Quantification of the percentage of cells in each cell cycle phase. ${ }^{*} \mathrm{P}<0.05$, compared with control group ( $\mathrm{n}=3$ ). (C) Effect of sulindac sulfide on the apoptosis of MCF-7 cells, cells were incubated for $72 \mathrm{~h}$ with various concentrations of sulindac sulfide. Percentage of cells in early (lower right box) and late (upper right box) apoptosis. (D) Quantification of the percentage of cells in early and late apoptosis. * $\mathrm{P}<0.05$, compared with control group ( $\mathrm{n}=3$ ).

assay. Samples $(50 \mu \mathrm{g})$ were resolved using $10 \%$ SDS-PAGE and transferred onto polyvinylidene difluoride (PVDF) membranes. Membranes were blocked in $5 \%$ milk for $1 \mathrm{~h}$ at room temperature, and subsequently stored overnight at $4^{\circ} \mathrm{C}$ on a shaker with the desired primary antibodies. Membranes were washed with TBS-Tween 20(T) and incubated for $1 \mathrm{~h}$ with the secondary antibody at room temperature. Following several washes with TBST, membranes were visualized using the Electro-Chemi-Luminescence reagent (Keygentec, Inc.). Each PVDF membrane was reported using $\beta$-actin as the loading control. The relative protein concentration was analyzed using Quantity One software (version 4.4.0; Bio-Rad Laboratories, Inc.).

Statistical analysis. Differences among groups were analyzed using one-way analysis of variance followed by Fisher's Least Significant Difference test. Results are presented as the mean \pm standard deviation. $\mathrm{P}<0.05$ was considered to indicate

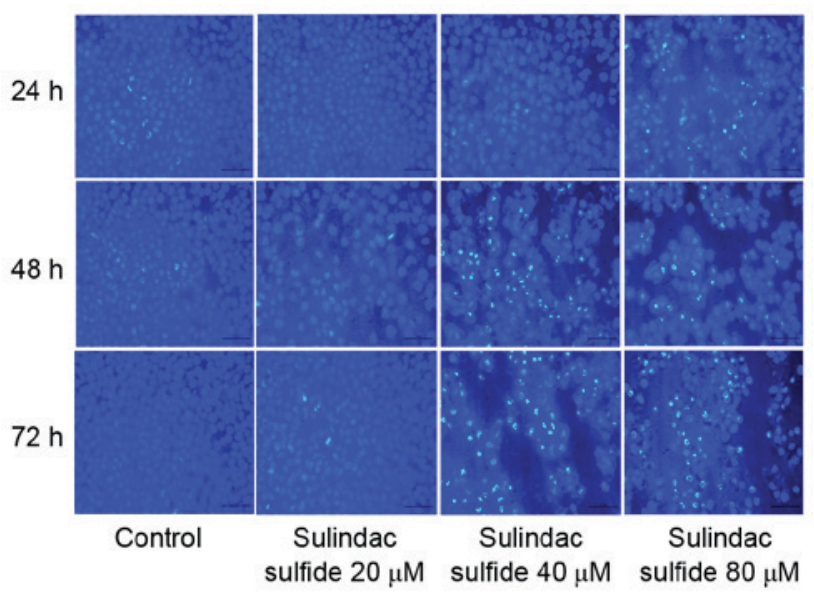

Figure 3. Dose- and time-dependent effects of sulindac sulfide in human breast cancer MCF-7 cells. Morphological changes in breast cancer MCF-7 cells induced by sulindac sulfide following incubation for different durations and concentrations. 

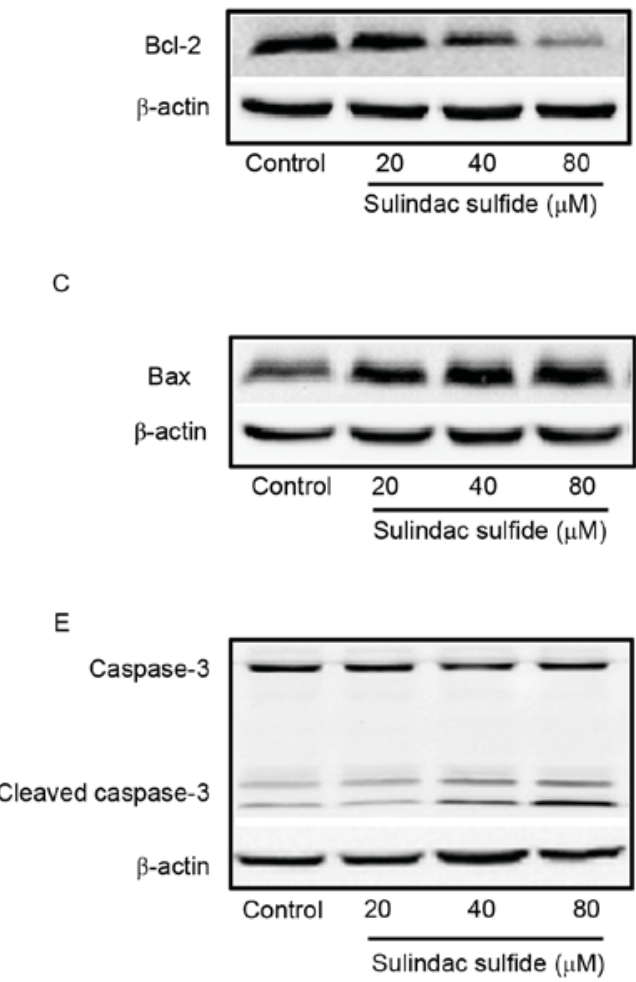
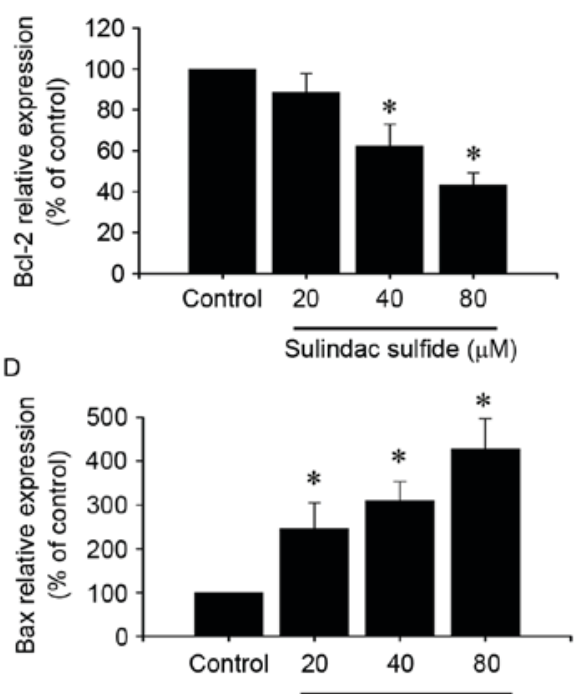

$\mathrm{F}$

Sulindac sulfide $(\mu \mathrm{M})$

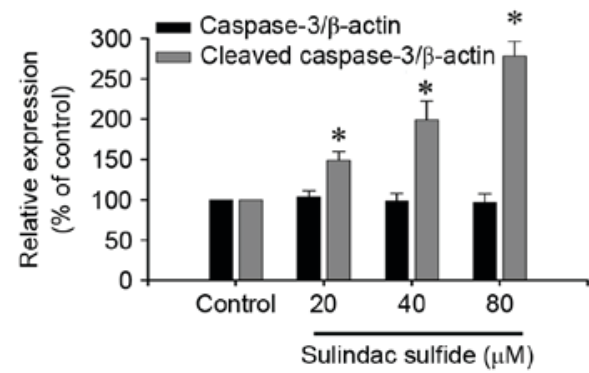

Figure 4. Cells were treated for $24 \mathrm{~h}$ with sulindac sulfide at the indicated concentrations. (A,C and E) The effect of sulindac sulfide on the expression of Bcl-2, Bax, Caspase- 3 and cleaved Caspase- 3 proteins. The expression of proteins was analyzed using western blotting. For each experiment, three assays were performed and one representative gel is presented. (B,D and F) Quantifcation of the relative expression of Bcl-2, Bax, Caspase-3 and cleaved Caspase-3 proteins. The density of the band (normalized to $\beta$-actin) presented as the mean \pm standard deviation is relative to that of $0 \mu$ mol/ $/ 1$ used as the control (designated as $100 \%$ ). ${ }^{*} \mathrm{P}<0.05$ vs. control group $(\mathrm{n}=3)$. Bax, apoptosis regulator; $\mathrm{Bcl}-2$, apoptosis regulator $\mathrm{Bcl}-2$.

a statistically significant difference. SPSS software (version 17.0; SPSS, Inc., Chicago, IL, USA) was used for statistical analysis.

\section{Results}

Inhibition ratio of cell proliferation. The effect of sulindac sulfide on MCF-7 cell proliferation was analyzed. The cells were incubated with sulindac sulfide $(20,40$ and $80 \mu \mathrm{mol} / \mathrm{l})$ for 24,48 or $72 \mathrm{~h}$. The data demonstrated that addition of varying doses of sulindac sulfide produced dose- and time-dependent increases in the inhibition ratio of cell proliferation (Fig. 1). The absolute values of inhibiting ratio are presented in Table I.

Effects of sulindac sulfide on cell cycle progression. Flow cytometric analysis demonstrated that there was no significant statistical significance between the $20 \mu \mathrm{mol} / \mathrm{l}$ group and the control in each cell cycle phase (Fig. 2A and B). However, there was a significant increase in $G_{0} / G_{1}$ phase cells with a simultaneous decrease in $S$ phase and $G_{2} / M$ phase cells in the 40 , and $80 \mu \mathrm{mol} / 1$ groups compared with that of the control group (Fig. 2A and B; P<0.05; Table II).

Effects of sulindac sulfide on the apoptosis of MCF-7 cells. Annexin V-FITC/PI staining was used to measure the percentage of apoptotic cells in response to sulindac sulfide treatments. Following $72 \mathrm{~h}$ of exposure to 20,40 or $80 \mu \mathrm{mol} / 1$ sulindac sulfide, the apoptotic rates were $25.31 \pm 6.75$, $36.7 \pm 12.71$, and $64.7 \pm 10.61 \%$, respectively, compared with $3.46 \pm 1.95 \%$ of control cells (Fig. 2C and D). These results suggest that sulindac sulfide can induce the apoptosis of MCF-7 cells in a dose-dependent.

Hoechst 33258 staining. The results of Hoechst 33258 staining demonstrated that sulindac sulfide could markedly induce the apoptosis of MCF-7 cells in a dose- and time-dependent manner (Fig. 3).

Effects of sulindac sulfide on protein expression. Cells were treated with different concentrations of sulindac sulfide or the control for $24 \mathrm{~h}$. The protein expression of Bcl-2 was downregulated, caspase-3 exhibited no significant change, and Bax and cleaved caspase- 3 were increased with increasing concentrations of sulindac sulfide (Fig. 4).

\section{Discussion}

Breast cancer is a malignant tumor that often occurs in females, its incidence is one of the highest among the female malignant tumor types. Therefore, early prevention, 
detection and treatment of breast cancer are of great value, and significance (16). The imbalance between proliferation and apoptosis of tumor cells is associated with tumor formation. Furthermore, loss of cell cycle regulation can lead to excessive cell proliferation and inhibition of cell apoptosis. Therefore, inhibiting tumor cell proliferation and inducing its apoptosis is an effective method for the treatment of tumors (17).

Sulindac sulfide can not only inhibit a variety of carcinogenic substances, but can also inhibit the growth of cancer cells and induce its apoptosis; however, the underlying mechanism remains unclear (4,18-20). A study performed by Kim et al (21) demonstrated that the combined treatment of sulindac and simvastatin augmented their anti-apoptotic potential in lung cancer cells through protein kinase B signaling-dependent downregulation of survivin. Furthermore, Fink et al (22) suggested that sulindac may be the most effective agent for colon cancer prevention in humans with low 15-hydroxyprostaglandin dehydrogenase levels, but may also be associated with inflammatory lesions in the colon. The results from a study by Katoumas et al (23) revealed that treatment with sulindac appears to delays the progression of oral premalignant lesions to oral squamous cell carcinoma, resulting in smaller and better differentiated tumors. These in vivo antineoplastic effects may be associated with its ability to decrease cell proliferation and to prevent survivin expression (23).

The results of the present study demonstrated that sulindac sulfide can significantly inhibit the proliferation of MCF-7 breast cancer cells, and the inhibitory effect was observed to be concentration- and time-dependent. The proliferation of cancer cells is regulated and controlled by key check points $G_{1} / S$ and $G_{2} / M$ in the cell cycle (24). In each cell cycle phase, along with the increasing concentrations of sulindac sulfide, the proportion of $G_{0} / G_{1}$ phase cells was increased significantly, and the proportion of $S$ and $G_{2} / M$ phase cells was reduced, demonstrated that sulindac sulfide inhibited the transition from $G_{0} / G_{1}$ to $S$ phase in breast cancer cells. Apoptosis is influenced by multiple gene regulatory proteins, the caspase family serve an important role in the process of apoptosis, among them caspase-3 is a primary apoptosis-mediating protease, which serves an essential role in the initiation of apoptosis through various factors. Caspase-3 can cause a cascade reaction following activation by upstream signaling factors Bax and Bcl-2, subsequently leading to cell apoptosis. The present study demonstrated that sulindac sulfide can activate the apoptosis-promoting Bax gene and inhibit Bcl-2, triggering downstream cascade activation of caspase-3, eventually leading to apoptosis. In the current study, the expression of Bcl-2 was decreased with increasing concentrations of sulindac sulfide, caspase- 3 exhibited no significant change. In addition, the expression of Bax and cleaved caspase-3 was increased following treatment with sulindac sulfide, suggesting that sulindac sulfide induces cell apoptosis.

The results of the present study demonstrated that sulindac sulfide can inhibit the proliferation and induce the apoptosis of MCF-7 cells, using a mechanism associated with alterations to the cell cycle and inhibition of Bcl-2 expression, thus activating caspase-3. However, the specific mechanism of sulindac sulfide remains unclear, as well as whether it can be effectively applied for the clinical treatment of breast cancer. The concentration and time course of sulindac sulfide in inhibiting proliferation, and inducing apoptosis of human breast cancer warrants further investigation.

\section{Acknowledgements}

Not applicable.

\section{Funding}

The present study was supported by the Natural Science Foundation Project of CQ (grant no. CSTC, 2010BB5111) and the Project Foundation of Chongqing Municipal Education Committee (grant no. KJ100308).

\section{Availability of data and materials}

The datasets used and analyzed in the present study are available from the corresponding author on reasonable request.

\section{Author's contributions}

HHS participated in the majority of experiments, performed the data analyses for these experiments and wrote the manuscript. YJZ planned the majority of experiments, analyzed the results and wrote parts of the manuscript. HW participated in the coordination of the study and reviewed the manuscript. LL and MC completed the cell proliferation assay and cell culture, revised the manuscript and helped perform data analysis. JJH designed the work that led to the submission and approved the final version. All authors read and approved the final manuscript.

\section{Ethics approval and consent to participate}

Not applicable.

\section{Consent for publication}

Not applicable.

\section{Competing interests}

The authors declare that they have no competing interests.

\section{References}

1. Span PN, Pollakis G, Paxton WA, Sweep FC, Foekens JA, Martens JW, Sieuwerts AM and van Laarhoven HW: Improved metastasis-free survival in nonadjuvantly treated postmenopausal breast cancer patients with chemokine receptor 5 del32 frameshift mutations. Int J Cancer 136: 91-97, 2015.

2. Fu J, Xu X, Kang L, Zhou L, Wang S, Lu J, Cheng L, Fan Z, Yuan B, Tian P, et al: miR-30a suppresses breast cancer cell proliferation and migration by targeting Eya2. Biochem Biophys Res Commun 445: 314-319, 2014.

3. Diller M, Schüler S, Buchholz S, Lattrich C, Treeck O and Ortmann O: Effects of estriol on growth, gene expression and estrogen response element activation in human breast cancer cell lines. Maturitas 77: 336-343, 2014. 
4. Lenik J: Preparation and characterization of a sulindac sensor based on PVC/TOA-SUL membrane. Mater Sci Eng C Mater Biol Appl 37: 383-389, 2014.

5. Giardiello FM, Hamilton SR, Krush AJ, Piantadosi S, Hylind LM, Celano P, Booker SV, Robinson CR and Offerhaus GJ: Treatment of colonic and rectal adenomas with sulindac in familial adenomatous polyposis. N Engl J Med 328: 1313-1316, 1993.

6. Beazer-Barclay Y, Levy DB, Moser AR, Dove WF, Hamilton SR, Vogelstein B and Kinzler KW: Sulindac suppresses tumorigenesis in the Min mouse. Carcinogenesis 17: 1757-1760, 1996.

7. Mahmoud NN, Boolbol SK, Dannenberg AJ, Mestre JR, Bilinski RT, Martucci C, Newmark HL, Chadburn A and Bertagnolli MM: The sulfide metabolite of sulindac prevents tumors and restores enterocyte apoptosis in a murine model of familial adenomatous polyposis. Carcinogenesis 19: 87-91, 1998.

8. Piazza GA, Alberts DS, Hixson LJ, Paranka NS, Li H, Finn T, Bogert C, Guillen JM, Brendel K, Gross PH, et al: Sulindac sulfone inhibits azoxymethane-induced colon carcinogenesis in rats without reducing prostaglandin levels. Cancer Res 57: 2909-2915, 1997

9. Thompson HJ, Jiang C, Lu J, Mehta RG, Piazza GA, Paranka NS, Pamukcu R and Ahnen DJ: Sulfone metabolite of sulindac inhibits mammary carcinogenesis. Cancer Res 57: 267-271, 1997.

10. Altuvia Y, Landgraf P, Lithwick G, Elefant N, Pfeffer S, Aravin A, Brownstein MJ, Tuschl T and Margalit H: Clustering and conservation patterns of human microRNAs. Nucleic Acids Res 33: 2697-2706, 2005

11. Lee YS, Choi D, Kim NY, Yang S, Jung E, Hong M, Yang D, Lenz HJ and Hong YK: CXCR2 inhibition enhances sulindac-mediated suppression of colon cancer development. Int J Cancer 135: 232-237, 2014.

12. Verma R, Brahmankar M, Kushwah L and Suresh B: Evaluating the inhibitory potential of sulindac against the bleomycin-induced pulmonary fibrosis in wistar rats. Environ Toxicol Pharmacol 36 769-778, 2013.

13. Liggett JL, Min KW, Smolensky D and Baek SJ: A novel COX-independent mechanism of sulindac sulfide involve cleavage of epithelial cell adhesion molecule protein. Exp Cell Res 326: 1-9, 2014.

14. Huang WW, Ko SW, Tsai HY, Chung JG, Chiang JH, Chen KT, Chen YC, Chen HY, Chen YF and Yang JS: Cantharidin induces $\mathrm{G} 2 / \mathrm{M}$ phase arrest and apoptosis in human colorectal cancer cells through inhibition of CDK1 activity and caspase-dependent signaling pathways. Int J Oncol 38 $1067-1073,2011$.
15. Zhang YT, Ouyang DY, Xu LH, Ji Y, Zha Q, Cai J and He X Cucurbitacin B induces rapid depletion of the G-actin pool through reactive oxygen species-dependent actin aggregation in melanoma cells. Acta Biochim Biophys Sin (Shanghai) 43 556-567, 2011.

16. Chen Q, Ouyang DY, Geng M, Xu LH, Zhang YT, Wang FP and He XH: Valproic acid exhibits biphasic effects on apoptotic cell death of activated lymphocytes through differential modulation of multiple signaling pathways. J Immunotoxicol 8: 210-218, 2011.

17. Greening DW, Ji H, Kapp EA and Simpson RJ: Sulindac modulates secreted protein expression from LIM1215 colon carcinoma cells prior to apoptosis. Biochim Biophy Acta 1834: 2293-2307, 2013.

18. Corbex M, Bouzbid S and Boffetta P: Features of breast cancer in developing countries, examples from North-Africa. Eur J Cancer 50: 1808-1818, 2014.

19. Li H, Yang AL, Chung YT, Zhang W, Liao J and Yang GY: Sulindac inhibits pancreatic carcinogenesis in LSL-Kras G12D-LSL-Trp53R172H-Pdx-1-Cre mice via suppressing aldo-keto reductase family 1B10 (AKR1B10). Carcinogenesis 34: 2090-2098, 2013.

20. Sinicrope FA and Penington RC: Sulindac sulfide-induced apoptosis is enhanced by a small-molecule Bcl-2 inhibitor and by TRAIL in human colon cancer cells overexpressing Bcl-2. Mol Cancer Ther 4: 1475-1483, 2005.

21. Kim YS, Seol CH, Jung JW, Oh SJ, Hwang KE, Kim HJ, Jeong ET and Kim HR: Synergistic effect of sulindac and simvastatin on apoptosis in lung cancer A549 cells through AKT-dependent downregulation of survivin. Cancer Res Treat 47: 90-100, 2015.

22. Fink SP, Dawson DM, Zhang Y, Kresak A, Lawrence EG Yang P, Chen Y, Barnholtz-Sloan JS, Willis JE, Kopelovich L and Markowitz SD: Sulindac reversal of 15-PGDH-mediated resistance to colon tumor chemo-prevention with NSAIDs. Carcinogenesis 36: 291-298, 2015.

23. Katoumas KM, Nikitakis N, Perrea D, Dontas I and Sklavounou A: In vivo antineoplastic effects of the NSAID sulindac in an oral carcinogenesis model. Cancer Prev Res (Phila) 8: 642-649, 2015.

24. Smalley W, Ray WA, Daugherty J and Griffin MR: Use of nonsteroidal anti-inflammatory drugs and incidence of colorectal cancer: A population-based study. Arch Intern Med 15: 161-166, 1999. 